Eliecer Díaz · Christine Güldenzoph · Markus Molis

Christopher McQuaid • Martin Wahl

\title{
Variability in grazer-mediated defensive responses of green and red macroalgae on the south coast of South Africa
}

Received: 15 October 2005/ Accepted: 21 March 2006/Published online: 16 May 2006

(C) Springer-Verlag 2006

\begin{abstract}
Variabilities in the responses of several South African red and green macroalgae to direct grazing and the responses of one green alga to cues from grazers were tested. We used two feeding experiments: (1) testing the induced responses of three red and one green algae to direct grazing by mesograzers and (2) a multi-treatment experiment, in which the direct and indirect effects of one macrograzer species on the green alga Codium platylobium were assessed. Consumption rates were assessed in feeding assays with intact algal pieces and with agar pellets containing non-polar extracts of the test algae. Defensive responses were induced for intact pieces of Galaxaura diessingiana, but were not induced in pellets, suggesting either morphological defence or chemical defence using polar compounds other than polyphenols. In contrast, exposure to grazing stimulated consumption of Gracilaria capensis and Hypnea spicifera by another grazing species. In the multi-treatment experiment, waterborne cues from both grazing and non-grazing snails induced defensive algal traits in C. platylobium. We suggest that inducible defences among macroalgae are not restricted to brown algae, but that both the responses of algae to grazers and of grazers to the defences of macroalgae are intrinsically variable and complex.
\end{abstract}

\section{Introduction}

It has been suggested that grazing can leave macroalgae better defended, more susceptible or have no effect

Communicated by J.P. Thorpe, Port Erin

E. Díaz $(\bowtie) \cdot$ C. McQuaid

Department of Zoology and Entomology, Rhodes University, P.O. Box 94, Grahamstown 6140, South Africa

E-mail: g03d4394@campus.ru.ac.za

Tel.: + 27-46-6038535

Fax: + 27-46-6228959

C. Güldenzoph · M. Molis · M. Wahl

Leibniz Institute of Marine Sciences, Düsternbrooker Weg 20,

24105 Kiel, Germany against future grazing (Adler and Karban 1994). However, on evolutionary time scales, grazing pressure should always tend to cause responses that increase algal fitness (Steinberg and Van Altena 1992). Literature suggests that it is possible to recognize two levels of grazing: macrograzing and mesograzing. Macrograzing is represented by macrograzers, which are mobile, generalist herbivores with large foraging ranges (Hay 1992). In this study, by macrograzers, we mean generalist herbivores with intermediate $\left(0.5-1 \mathrm{~m}^{2}\right)$ foraging ranges, such as urchins, or large foraging ranges (up to $5 \mathrm{ha}$ ), such as fish (Carpenter 1986). These grazers can deplete the daily primary productivity in tropical areas or eat a whole individual alga, greatly reducing algal fitness (Lubchenco and Gaines 1981; Lewis et al. 1987; Hay and Fenical 1988). In subtropical areas macrograzers can have strong effects on algal distribution and algal biomass (McQuaid and Froneman 1993). Mesograzing is represented by the less mobile species specialized to live in algae (Hay 1992). They usually exhibit smaller sizes than macrograzers $(<2 \mathrm{~cm})$ and small foraging ranges $\left(1-100 \mathrm{~cm}^{2}\right)$. Examples of mesograzers are amphipods, isopods, snails and some limpets (Hay et al. 1988; Pavia and Toth 2000). Mesograzers have less impact on the algal productivity, biomass and distribution than macrograzers, unless they are at high densities (Underwood and Jernakoff 1984; Carpenter 1986; Hay 1992). Linked to the strong effects that grazers may have on the spatial distribution and community structure of macroalgae in coastal marine systems is the ability of algae to respond in a variety of ways.

Among the forms of defence mediated by grazing are non-induced morphological defences such as calcareous structures and frond toughness, which increase the structural rigidity of certain morphological features; these have been evolved under the strong selective pressure of grazing (Littler and Littler 1980; Steneck and Watling 1982; Hay 1992). In contrast inducible morphological defences operate over ecological time scales (reviewed by Cronin 2001). The best known example of an induced morphological defence is given by the dif- 
ferent growth forms of the alga Padina (see Lewis et al. 1987). A more widespread defence strategy involves the use of secondary metabolites, especially polar compounds such as polyphenols, to deter grazers (but see Deal et al. 2003), and the use of non-polar compounds (Hay 1992). Such chemical defences can be categorized as constitutive or inducible. Constitutive defences involve continuously high levels of deterrent secondary compounds, irrespective of grazing intensity, and are fixed as a trait in evolutionary time as with non-induced morphological defences (Adler and Karban 1994; Steinberg 1994) in response to permanently high levels of grazing (Paul and Van Alstyne 1992; Hay 1996; Karban et al. 1997); e.g. the green alga Avrainvillea longicaulis produces a brominated diphenylmethanol called avrainvilleol that deters grazing by coral reef fishes (Hay et al. 1990). Activated defences are a type of constitutive defence where permanently stored precursors are converted into deterrent compounds following physical or grazing damage; e.g. constitutive defences in the red alga Polysiphonia hendry and the green algae Ulva californica deter grazing by the urchin Strongylocentrotus droebachiensis (Van Alstyne et al. 2001). Constitutive defences are related to high levels of grazing and can operate extremely rapidly, on scales of seconds to minutes (Paul and Van Alstyne 1992; Cetrulo and Hay 2000; Van Alstyne et al. 2001). Inducible chemical defences are based on the slower supply of defensive compounds (commonly polyphenols and some non-polar compounds) which increase days after damage by mesograzers. This latter defence type has been confirmed in marine systems for brown algae (e.g. Van Alstyne 1988; Cronin and Hay 1996; Pavia and Toth 2000; Toth and Pavia 2000; Sotka et al. 2002; Taylor et al. 2002; Rohde et al. 2004; Macaya et al. 2005) and for red alga is apparently based on either polar compounds, toughness, or synergism between polar and non-polar compounds (e.g. Weidner et al. 2004; Ceh et al. 2005). The induction of chemical defences seems to be a strategy that offers no deterrence by low concentration of the chemical compounds or when the algae are not stimulated to increase the concentration of the deterrent compounds. However, if the level of grazing becomes a danger to algal fitness, the alga reacts, increasing the concentration of its chemical compounds and becoming unpalatable (Cronin and Hay 1996). Chemical compounds (most of them non-polar) extracted from red algae can have stronger deterrent properties than the polyphenols of brown algae (Hay and Fenical 1988; Steinberg and Van Altena 1992).

Within assemblages of grazers and algae, certain algal compounds may act as deterrents for one kind of macrograzer but may stimulate feeding by another (Sakata et al. 1986; Cetrulo and Hay 2000). This pattern has been observed between sea urchins and fish, and also between mesograzers and macrograzers; many mesograzers are not affected by compounds that deter macrograzers (Hay et al. 1990; Duffy and Hay 1994). This indicates that there is great variability in the effects of these chemical compounds on different grazers. This variability may be partially explained by differences in physiology of the grazers and partially by spatial and temporal differences in the chemical structures of the compounds produced by algae (Hay 1992, 1996, 1997; Cetrulo and Hay 2000; Weidner et al. 2004). Most theories that explain the diversity in responses between macro and mesograzers are supported by the fact that some mesograzer species profit by sheltering within defended algae, in order to avoid predation by omnivorous macrograzers like fish (Hay et al. 1988, 1990, 1994; Hay 1992, 1997; Duffy and Hay 1991). Here the costs of tolerating algal defensive compounds are less than the costs of potential predation and, as a result, these chemical compounds can be attractive to mesograzers.

Various factors can induce chemical defences, including changes in abiotic factors such as UV irradiance (Pavia et al. 1997) and nutrients (Yates and Peckol 1993; Peckol et al. 1996), as well as changes in biotic factors, particularly grazing. Grazing effects can be further classified as (a) direct grazing upon the alga (Cronin and Hay 1996; Pavia and Toth 2000; Sotka et al. 2002); (b) grazing upon a neighbouring alga that causes the release of an alerting cue into the water (Toth and Pavia 2000); and (c) the simulation of grazing by artificial damage or clipping (Van Alstyne 1988; Pavia et al. 1997; Hammerstrom et al. 1998; Pavia and Toth 2000). In the "talking-trees" debate of terrestrial systems, it is suggested that a chemical cue from a damaged plant passes through the atmosphere to an undamaged plant. The latter is consequentially alerted to a possible predator and is hence able to defend itself against it (Baldwin and Schultz 1983; Bruin et al. 1995). This hypothesis has been criticized due to a lack of studies that provide a complete picture about the whole process, such as the type of damage, nature of the cue, and how the receiver is stimulated (Bruin et al. 1995). In marine systems little attention has been paid to the possibility of a grazed alga releasing waterborne cues that stimulate an increase in the production of secondary metabolites in an ungrazed neighbouring alga. There are some examples from brown algae (Toth and Pavia 2000; Rhode et al. 2004; Macaya et al. 2005). One of these examples is the brown alga Ascophyllum nodosum, which responds to waterborne cues released when neighbouring algae are grazed by Littorina obtusata by increasing its production of secondary metabolites. In this case, it was not clear if the increase in deterrent compounds was induced by chemicals produced by the grazer or by exudates from the neighbouring grazed algae (Toth and Pavia 2000).

The objectives of this study were the following. (1) To identify possible induced responses (stimulatory or deterrent) in one green and three red macroalgae in response to different grazers. We tested the responses to artificial food based on non-polar compounds, as these are predominant in green and red algae and we performed one polyphenol assay with Galaxaura diessingiana. (2) To assess the different mechanisms by which 
grazers can stimulate the induction of chemical responses in Codium platylobium. For this we used direct and indirect grazing treatments with the macrograzer Turbo sarmaticus, to determine if the waterborne cues were released by the grazed macroalgae, its grazed neighbours or by the grazer itself.

\section{Materials and methods}

Set-up

Experiments were carried out in the coastal laboratory

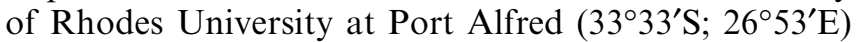
on the south coast of South Africa, between February and May 2003. All organisms used in the experiments were collected randomly from the field in buckets with abundant seawater from the nearby rocky shores (20 min to laboratory).

The organisms (Table 1) comprised the two green algae Codium platylobium (fronds up $50 \mathrm{~cm}$ long and $7 \mathrm{~mm}$ wide) and C.extricatum (cylindrical axes $15 \mathrm{~cm}$ long and $7 \mathrm{~mm}$ diameter) and three red algae Galaxaura diessingiana $(80 \times 5 \mathrm{~mm})$, Gracilaria capensis $\left(150 \times 5 \mathrm{~mm}^{2}\right)$ and Hypnea spicifera $(20 \mathrm{~cm} \times 2 \mathrm{~mm})$. In addition two mesograzer species were used in our experiments: Paridotea rubra (Isopoda, length $\pm 25 \mathrm{~mm}$ ), Tricolia capensis (Gastropoda, operculum diameter $\pm 4.5 \mathrm{~mm}$ ) and the macrograzer Turbo sarmaticus (Gastropoda, operculum diameter $\pm 36 \mathrm{~mm}$ ). The snail Tricolia capensis and the isopod P. rubra were collected from the branches of H. spicifera.

The sites chosen for collection were Rufanes $\left(33^{\circ} 45^{\prime} \mathrm{S}\right.$, $\left.26^{\circ} 96^{\prime} \mathrm{E}\right)$ and Old Woman's $\left(33^{\circ} 45^{\prime} \mathrm{S}, 27^{\circ} 15^{\prime} \mathrm{E}\right)$, both of which are categorized as wave-sheltered sites (Lindsay 1998). The shore at Rufanes consists of medium $(50 \mathrm{~cm}$ diameter) to large $(2 \mathrm{~m})$ sandstone boulders. The shore at Old Woman's forms a gently sloping sandstone platform. The low shore at both sites is dominated by the red alga $H$. spicifera, which has creeping rhizomes and exhibits nearly $100 \%$ cover in this zone. This alga is inhabited by numerous mesograzers such as $T$. capensis and $P$. rubra. The green alga $C$. extricatum is found at the same shore level, in crevices and pools. The snail Turbo sarmaticus extends from this zone into the subtidal. Galaxaura diessingiana, which has flat axes with a lime-impregnated skin, and Gracilaria capensis, which is foliose with large thalli, appear as scattered sub-dominants in the shallow subtidal, as does the green foliose C. platylobium, which grows on sandy bottoms.

Alga-grazer combinations were determined in quantitative pilot assays in the laboratory. The pilot studies were carried out in different individual aquaria with specific alga-grazer combinations. We weighed the alga at the beginning and at the end of the study. Many algagrazer combinations were tested, but not all grazers consumed all algae and many algae showed bleaching. We chose alga-grazer combinations in which algae remained healthy in the absence of grazing and grazers showed continuous consumption rates (Table 1). All combinations were artificial except $H$. spicifera with Tricolia capensis (personal observation), as $T$. capensis inhabits the rhizomes of $H$. spicifera. The consumption of algae is the principal requirement to test for responses in macroalgae, so we required combinations where the alga was visibly damaged. For the screening experiment, appropriate numbers of grazers per aquarium were determined in quantitative pilot assays in the laboratory, where we could perceive visible damage by the grazer (Table 1). For the multi-treatment experiment, consumption alone was not enough to test for the direct and indirect induction of response; we needed to know if the alga first exhibits direct induction. For this reason we ran a pilot study in which we exposed pieces of

Table 1 Experimental overview showing the alga-grazer combinations used in the screening and multi-treatment experiments

\begin{tabular}{|c|c|c|c|c|c|c|c|c|c|}
\hline \multirow[t]{3}{*}{ Alga } & \multirow[t]{3}{*}{ Grazer } & \multirow[t]{3}{*}{ Experiment } & \multirow[t]{3}{*}{$\mathrm{dA}$} & \multirow{2}{*}{\multicolumn{2}{|c|}{ Treatment }} & \multicolumn{4}{|c|}{ Feeding assays } \\
\hline & & & & & & \multicolumn{2}{|c|}{$\begin{array}{l}\text { Intact } \\
\text { algae }\end{array}$} & \multicolumn{2}{|c|}{$\begin{array}{l}\text { Food } \\
\text { pellets }\end{array}$} \\
\hline & & & & $\mathrm{nT}$ & $\mathrm{dT}$ & ni & di & $\mathrm{np}$ & $\mathrm{dp}$ \\
\hline $\begin{array}{l}\text { Galaxaura diessingian } \\
\text { Pilot consumption }=\end{array}$ & $\begin{array}{l}\text { na Paridotea rubra } \\
=0.002 \pm 0.001 \mathrm{~g} \mathrm{ind}^{-1} \mathrm{day}^{-1}\end{array}$ & Screening & 10 & 5 & 6 & 5 & 3 & 5 & 3 \\
\hline $\begin{array}{l}\text { Gracilaria capensis } \\
\text { Pilot consumption }=\end{array}$ & $\begin{array}{c}\text { Paridotea rubra } \\
=0.003 \pm 0.001 \mathrm{~g} \mathrm{ind}^{-1} \mathrm{day}^{-1}\end{array}$ & Screening & 10 & 5 & 6 & 5 & 3 & 5 & 3 \\
\hline $\begin{array}{l}\text { Hypnea spicifera } \\
\text { Pilot consumption }=\end{array}$ & $\begin{array}{c}\text { Tricolia capensis } \\
0.001 \pm 0.002 \mathrm{~g} \mathrm{ind}^{-1} \mathrm{day}^{-1}\end{array}$ & Screening & 10 & 10 & 6 & 10 & 3 & 10 & 3 \\
\hline $\begin{array}{l}\text { Codium extricatum } \\
\text { Pilot consumption }=\end{array}$ & $\begin{array}{c}\text { Tricolia capensis } \\
=0.001 \pm 0.002 \mathrm{~g} \mathrm{ind}^{-1} \mathrm{day}^{-1}\end{array}$ & Screening & 10 & 10 & 6 & 10 & 3 & 10 & 3 \\
\hline $\begin{array}{l}\text { Codium platylobium } \\
\text { Pilot study = grazed }\end{array}$ & $\begin{array}{c}\text { Turbo sarmaticus } \\
0.2 \pm 0.02 \text { and non-grazed } 0 .\end{array}$ & $\begin{array}{l}\text { Multi-treatment } \\
11 \pm 0.05 \mathrm{~g} \mathrm{ind}^{-1}\end{array}$ & 14 & 1 & 7 & 1 & 1 & 1 & 1 \\
\hline
\end{tabular}

The duration in days is given for the acclimation phase (dA), treatment phase (dT), duration of intact feeding assays (di) and artificial food (pellets) feeding assays (dp). $n$ indicates the number of grazers in the different phases: nT during the treatment phase, ni during the intact feeding assays and $\mathrm{np}$ during the artificial feeding assays. Pilot consumption shows the daily consumption per grazer 
C. platylobium to Turbo sarmaticus and pieces that remained without grazers, and then we measured the consumption (Table 1).

Seawater was drawn directly from the sea, passed through a filter of mesh size $25 \mu \mathrm{m}$ into three $100 \mathrm{l}$ plastic tanks in the laboratory. Using $0.5 \mathrm{~cm}$ diameter hoses, 60 (40 for the screening experiment and 20 for the multi-treatment experiment) transparent 21 plastic containers (referred to as experimental units or EUs) were individually supplied with a non-recirculating supply of fresh seawater at a constant flow rate of $1 \mathrm{ml} \mathrm{s}^{-1}$. For C. platylobium, the flow rate was increased to $4 \mathrm{ml} \mathrm{s}^{-1}$ as this species suffered fungal infection at lower flow rates. These different flow regimes did not confound the results because $C$. platylobium was not compared with the other species. The light regime was $12: 12 \mathrm{~h}$ light:dark with a light intensity of $19.3 \pm 5.04 \mu \mathrm{mol} \mathrm{m}{ }^{-2} \mathrm{~s}^{-1}$ supplied by daylight bulbs (60 W, General Electric, Enrich Spot). Each (EU) was divided by a perforated PVC mesh (mesh size $<1 \mathrm{~mm}$ ) into an upstream compartment and a downstream compartment.

Two experiments were conducted to test for inducible responses: (1) the screening experiment to test different responses under direct grazing used four algal species: G. diessingiana, G. capensis, H. spicifera and C. extricatum (40 EUs) and (2) the multi-treatment experiment used one algal species, C. platylobium (20 EUs), to test the effect of different grazing inductions such as direct grazing, waterborne cues and presence of the grazer on the algal responses. Each experiment was divided into: (a) an acclimation phase, aimed at minimizing the effects of the unknown grazer histories on each alga and adjusting algae to the experimental conditions; (b) a treatment phase, in which algae were exposed to grazers; and (c) finally after the treatment phase feeding assays tested for induced responses. Because the red alga Galaxaura diessingiana showed inducible defences, an extra experiment was conducted to assess the induction of polyphenols. This basic design was developed from the published work of Weidner et al. (2004), Rhode et al. (2004) and Ceh et al. (2005).

\section{Acclimation phase for screening and multi-treatment experiments}

Before starting the experiment, haphazardly collected individual algae were cleaned of all visible epiphytes; apical pieces ( 3 or 4 apices per plant) were removed $3 \mathrm{~cm}$ from the tips and placed in one container. At the beginning of the acclimation phase, three (for the screening experiment) and four (for the multi-treatment experiment) similarly sized pieces of the same algae were drawn randomly from the container and placed without grazers in each EU (initial weight mean $\pm \mathrm{SD}$ : $G$. diessingiana $0.13 \pm 0.03 \mathrm{~g}$, Gracilaria capensis $0.49 \pm 0.12 \mathrm{~g}$, H. spicifera $0.37 \pm 0.12 \mathrm{~g}$, C. extricatum $0.91 \pm 0.21 \mathrm{~g}$ and $C$. platylobium $1.52 \pm 0.55 \mathrm{~g})$. Each piece was marked for later identification (using different colours of thread) and weighed. One piece was later used for the intact feeding assays, the second piece was used in artificial food feeding assays, while the third piece was left in the EU to test for autogenic changes (changes in mass due to growth or degeneration). The fourth piece in the multi-treatment experiment was used to calculate the algal growth rate of $C$. platylobium during the treatment phase. For each of the three algal species in the screening experiment, we set up 10 EUs, while 20 EUs were used per alga-consumer combination in the multi-treatment experiment. For the duration of the acclimation phase see Table 1 .

\section{Treatment phase}

Screening experiment To assess the relative effects of direct grazing on algal palatability during the feeding assays phase, pieces of Galaxaura diessingiana, Gracilaria capensis, $H$. spicifera and $C$. extricatum were exposed to grazers in five randomly selected EUs (treatment) while the remaining five EUs were left without grazers (control). The grazers used during the experiment were P. rubra for Galaxaura diessingiana and Gracilaria capensis and Tricolia capensis for H. spicifera and $C$. extricatum. Grazer-alga combinations, the duration and number of grazers are provided in Table 1 and Fig. 1.

Multi-treatment experiment Four treatments were applied to assess the relative effects of Turbo sarmaticus grazing on C. platylobium. The four treatments were: (1) DG, direct grazing where one grazer and four algal pieces were placed together in the downstream compartment while the upstream compartment was empty; (2) IG, indirect grazing where four pieces of test algae were in the downstream compartment and received water from the upstream compartment containing one snail and one additional piece of the same alga species; (3) PG, presence of grazer where one grazer was kept in the upstream compartment excluded from four pieces of test algae in the downstream compartment; and (4) no grazers (control), four pieces of test algae were positioned in the downstream compartment while the upstream compartment was empty (Fig. 1). T. sarmaticus is a generalist grazer that can cause significant damage to algae while feeding (Foster and Hodgson 1998) and we chose $C$. platylobium and $T$. sarmaticus as the algagrazer combination for the multi-treatment experiment. T. sarmaticus consistently ate $C$. platylobium, but not the other species of algae. In addition the pilot study showed that grazed pieces of $C$. platylobium were more preferred than non-grazed pieces $(t=-2.97, d f=4, P=0.04)$, suggesting an inducible response and we assumed that this alga-grazer combination would be suitable for testing the indirect induction mediated by waterborne cues, as attack by a macrograzer would have a higher impact on the algae and could trigger the release of waterborne cues. Duration of the treatment phase for 
Fig. 1 Diagram of the experiments used to induce responses in algae. Screening experiment consisted of two treatments, direct grazing $(D G)$ and control $(C)$. Multitreatment experiment consisted of four treatments, direct grazing $(D G)$, indirect grazing $(I G)$, presence of grazer $(P G)$ and control $(C)$. The letter ' $A$ ' indicates alga and ' $+A$ ' indicates an additional piece of alga to test for waterborne cues. The letter ' $G$ ' indicates grazer

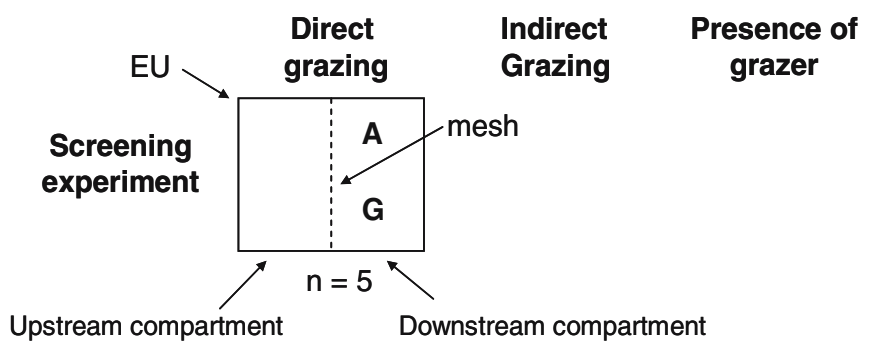

Control

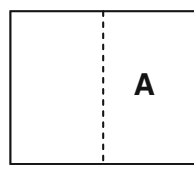

$\mathrm{n}=5$
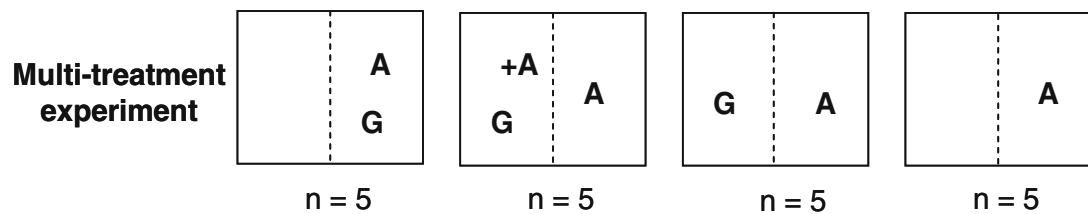

$\mathrm{n}=5$ the screening and multi-treatment experiments was in the range of induction times found in the literature (Hammerstrom et al. 1998; Toth and Pavia 2000).

\section{Feeding assays for screening and multi-treatment experiments}

Following the treatment phase, the algal test pieces were removed from the EUs, blotted dry with paper tissue and individually weighed (SARTORIUS scale, precision $0.0001 \mathrm{~g}$ ) at the beginning and end of the feeding assays. In the no-choice feeding assays, we used either intact pieces to assess the combined effects of morphological and chemical defensive algal traits or agar-based artificial food (pellets) to assess the defence response of nonpolar secondary metabolites alone. To avoid grazer adaptations to food quality, we used the same grazer species but different non-starved individuals in the feeding assays and in the treatment phase of the induction experiments, as recommended by Cronin and Hay (1996). All feeding assays were conducted in 21 transparent plastic containers of seawater and the seawater was changed once per day. Consumption by a grazer on a single alga piece, including a correction factor to account for autogenic changes of intact algae incubated in a feeding assay, was calculated as:

Consumption $=\left[T_{\mathrm{o}}\left(\frac{C_{\mathrm{f}}}{C_{\mathrm{o}}}\right)-T_{\mathrm{f}}\right]$,

where "o" and "f" were the pre- and post-assay wet masses, respectively, of the intact plant piece consumed in a feeding assay $(T)$ and a non-consumed piece controlling for autogenic changes $(C)$ (Cronin and Hay 1996). The consumption of artificial food was calculated as the difference in wet mass of an artificial food pellet at the beginning and end of a feeding assay. The feeding assays were conducted in random order, and the consumption of the treated pieces was compared with the appropriate control. Each feeding assay continued until an algal piece showed a perceivable loss of biomass (see Table 1 for the duration of experiments and densities of grazers). During the feeding assays of the multi-treatment experiment we lost several pieces used as controls for autogenic changes through fungal infection. We calculated the average of the remaining pieces to obtain the $\left(C_{\mathrm{f}} / C_{\mathrm{o}}\right)$ value. This was possible because growth rate did not change during the treatment phase (see Results section).

\section{Polyphenol analysis in Galaxaura diessingiana}

An extra experiment was carried out to test for the deterrent role of polyphenols. Twenty algal individuals of $G$. diessingiana were collected. Half were exposed to the isopod P. rubra (1 alga and 2 grazers per EU; treatment, $n=10)$ and the other half were kept free of grazers (1 alga per EU; control, $n=10)$. Six days later, $0.1 \mathrm{~g}$ of each algal piece was submerged in $4 \mathrm{ml}$ of $80 \%$ methanol for $48 \mathrm{~h}$ in total darkness in order to extract polyphenols. To determine the concentration of polyphenols per gram, we used the Folin-Ciocalteu (Sigma) assay (Waterman and Mole 1994; Van Alstyne 1995; Hammerstrom et al. 1998) and compared this with a phloroglucinol standard, which was used to calculate the calibration slope (Waterman and Mole 1994). We added $5 \mathrm{ml}$ of the reagent Folin-Ciocalteu to $0.18 \mathrm{ml}$ of the polyphenol extract. After $5 \mathrm{~min} 0.4 \mathrm{ml}$ of a sodium carbonate solution $\left(2 \mathrm{~g} \mathrm{ml}^{-1}\right)$ was added and the volume was made up to $6.3 \mathrm{ml}$ with deionized water. After $2 \mathrm{~h}$ we measured the absorbance at $760 \mathrm{~nm}$ in a Shimadzu UV-1201 spectrophotometer.

Assessment of growth rates in the multi-treatment experiment

The growth rate of $C$. platylobium exposed to $T$. sarmaticus was calculated using the fourth intact algal piece for each treatment. The formula used was: growth rate $=\left[T_{\mathrm{f}} / T_{\mathrm{o}}\right] /$ time, where $T_{\mathrm{o}}$ is the mass of the algal piece at the beginning and $T_{\mathrm{f}}$ the mass at the end of the treatment phase. 
Preparation of agar-based artificial food pellets containing non-polar algal extracts

We extracted secondary metabolites using dichloromethane, which is a highly volatile solvent and is commonly used to extract lipid-soluble compounds, which are relatively non-polar secondary metabolites. Secondary metabolites are often responsible for chemical defences in red and green algae (Kazlauskas et al. 1980, 1981; Paul et al. 2001; Steinberg et al. 2001). For the preparation of artificial food, one algal piece was removed from each EU at the end of each treatment phase and was extracted in $2 \mathrm{ml}$ dichloromethane per $0.5 \mathrm{~g}$ algal wet mass for $48 \mathrm{~h}$ at room temperature (Hay et al. 1994; Ceh et al. 2005). Extracts containing the non-polar fraction of algal chemicals were poured over $1 \mathrm{~g}$ of freeze dried Ulva fasciata powder and allowed to evaporate for $48 \mathrm{~h}$ at room temperature. Eight millilitres of distilled water was then added. Afterwards, a mixture of $0.36 \mathrm{~g}$ agar-agar in $6 \mathrm{ml}$ distilled water was boiled and mixed with the chemically tagged Ulva powder. The hot mixture was flattened between two glass plates $(1 \mathrm{~mm}$ gap) on a $2 \mathrm{~cm}^{2}$ mesh used to provide stability to the artificial food preparation. In order to make artificial food, it is necessary to use powder from an undefended alga such as $U$. fasciata, which has been tested in similar feeding assays (Weidner et al. 2004).

\section{Statistical analysis}

We tested for the normality and homogeneity of variances using Shapiro-Wilk's $W$ and Cochran $C$ tests, respectively. Data were transformed using natural logarithms when necessary; if the transformation was unsuccessful, non-parametric tests were used. The consumption rates of grazers on the control and treated intact algal pieces (screening experiment), for intact and for artificial food feeding assays, were analysed using twotailed $t$-tests or $U$-tests. The effects of different grazer treatments (multi-treatment experiment) were analysed using a one-way ANOVA or Kruskal-Wallis ANOVA when the data were neither parametric nor homogeneous. A Newman-Keuls post-hoc test determined the sources of any significant differences (Underwood 1997). In the screening and multi-treatment experiments, there was the possibility that two pieces of alga from the same plant would be compared. We assumed independence as the probability of such non-independence was low (7 and $4 \%$, respectively, for the two experiments).

\section{Results}

Screening experiment

Intact algae Grazing by the isopod P. rubra significantly reduced palatability in directly grazed pieces of G. diessingiana with the control algae being significantly preferred $(t=-4.45, d f=8, P=0.002)$. In contrast, directly grazed pieces of the red alga Gracilaria capensis were significantly preferred over the control $(t=-2.39$, $d f=8, P=0.043$; Fig. 2a). The latter trend, although not significant, was detected for $H$. spicifera algal pieces exposed to Tricolia capensis $(t=1.36, d f=8$, $P=0.212$; Fig. 2a). Similarly, a non-significant trend of enhanced grazing in the treated algae was detected for C. extricatum plants $(U=11, P=0.754$; Fig. 2a).

Artificial food Palatability of artificial food (containing non-polar algal extracts) showed significant differences only for $H$. spicifera $(t=2.4, d f=8, P=0.042)$, which showed the significant chemical stimulation by treated pieces exposed to grazers (Fig. 2b).

The algae Galaxaura diessingiana $(t=-0.89$, $d f=8, \quad P=0.399)$, Gracilaria capensis $(t=-0.17$, $d f=8, P=0.865)$ and $C$. extricatum $(t=1.476$, $d f=8, P=0.178)$ did not show significant differences.

\section{Polyphenol analysis in Galaxaura diessingiana}

The concentration of polyphenols for $G$. diessingiana was (mean $\pm \mathrm{SD}$ ) $0.4 \pm 0.3 \mathrm{mg} \mathrm{g}^{-1}$ wet mass for the
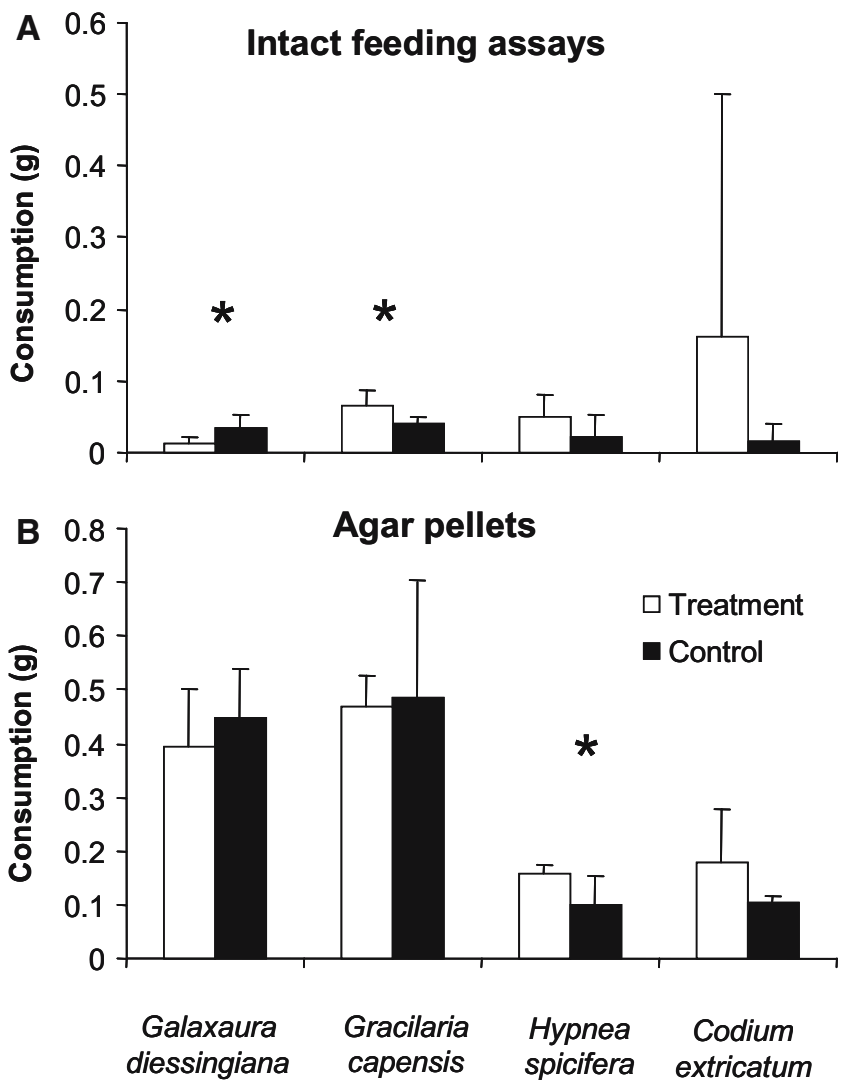

Fig. 2 Mean ( + SD) consumption of different algae by two mesograzers (isopod Paridotea rubra and the snail Tricolia capensis) in the screening experiment. a Intact feeding assays. b Feeding assays based on artificial food pellets containing non-polar compounds. Asterisks indicate significant differences. $n=5$ per treatment 
treated pieces and $1.3 \pm 1.7 \mathrm{mg} \mathrm{g}^{-1}$ wet mass for the controls. No significant difference in the concentration of polyphenols was detected between the grazed and control pieces $(t=-1.23, d f=18, P=0.233)$.

\section{Multi-treatment experiments}

Intact algae Snail consumption in feeding assays was significantly different among the algae exposed to different grazing treatments (one-way ANOVA: $F_{3,12}=3.56, P=0.039$; Fig. 3a). Post-hoc NewmanKeuls tests indicated that consumption rates on indirect grazing algal pieces were significantly lower than on algal pieces exposed to direct grazing treatments $(P=0.042)$.

Artificial food Snail consumption of artificial food was significantly affected by grazing treatments from the induction experiment (one-way ANOVA: $F_{3,14}=3.56$, $P=0.041$; Fig. 3b). Newman-Keuls post-hoc tests
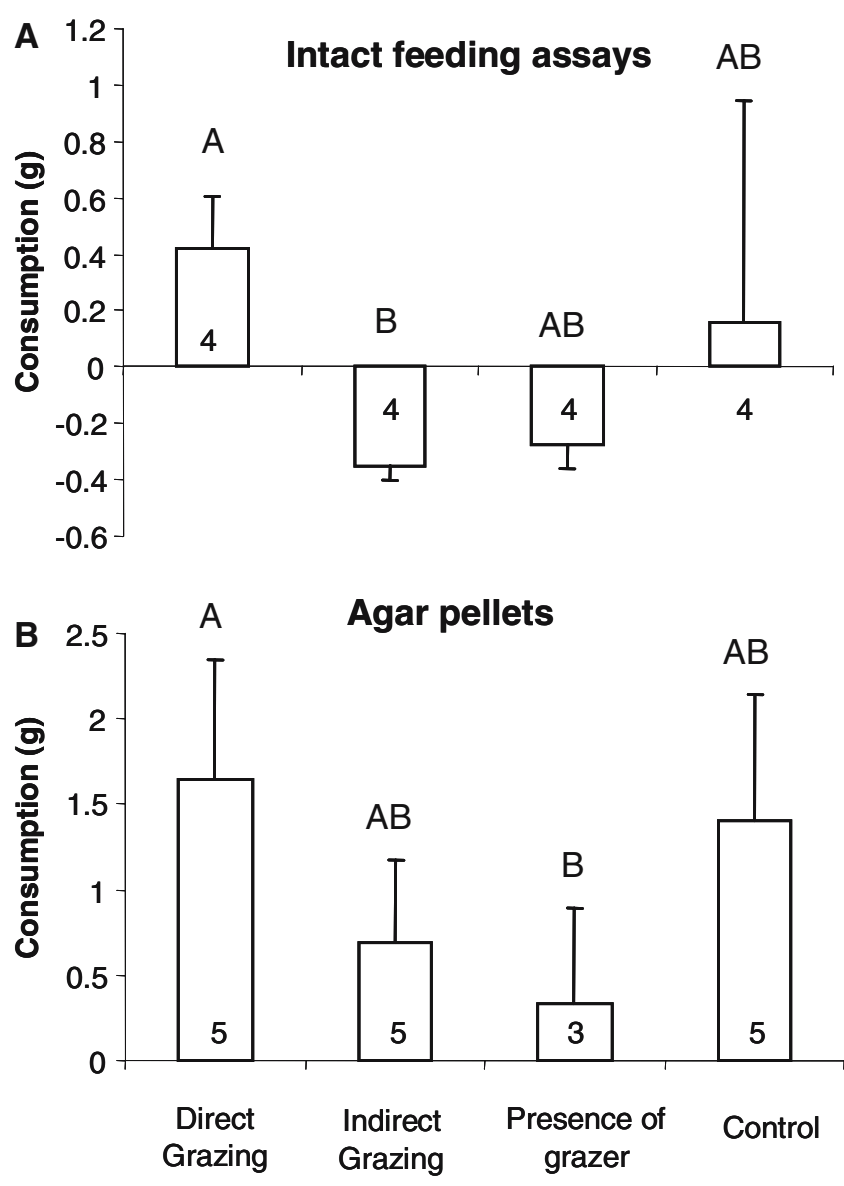

Fig. 3 Mean $(+$ SD) consumption in different grazing treatments by the macrograzer Turbo sarmaticus feeding on the alga Codium platylobium. a Intact feeding assays. b Feeding assays based on artificial food pellets containing non-polar compounds. Different letters indicate the significant difference in consumption. The numbers in bars indicate the replication. The autogenic change used was $(n=8) 0.85$ indicated that the consumption rates on algal pieces exposed to the presence of grazers were significantly lower $(P=0.043)$ than on pieces exposed to direct grazing.

Growth rate

The growth rates of $C$. platylobium in the different treatments exposed to Turbo sarmaticus did not show any significant difference (Kruskal-Wallis, $H=0.508$, $n=5$ for all treatments, $P=0.917$ ).

\section{Discussion}

Most references to inducible defences are restricted to the brown algae, particularly the fucales (Van Alstyne 1988; Cronin and Hay 1996; Pavia and Toth 2000; Toth and Pavia 2000; Sotka et al. 2002; Taylor et al. 2002; Rohde et al. 2004; Macaya et al. 2005), with two recent reports of chemical defences in red algae (Weidner et al. 2004; Ceh et al. 2005). We found grazing-mediated changes in palatability for three red algae and one out of the two green algae analysed. Among the red algae, intact pieces of $G$. diessingiana produced defences when exposed to the isopod P. rubra, whereas intact Gracilaria capensis and pellets of $H$. spicifera showed increased palatability for mesograzers. The green alga $C$. extricatum showed no changes in palatability, whereas the palatability of $C$. platylobium decreased in response to waterborne cues from nearby grazed conspecifics and of non-grazing consumers. These findings indicate that the defence mechanisms mediated by grazing are both variable and plastic.

Induced defences in the red alga Galaxaura diessingiana

Intact non-grazed control pieces of $G$. diessingiana were preferred by the isopod $P$. rubra over grazed pieces, indicating that anti-herbivore defence was induced in the grazed pieces. This suggests that the defence was due either to the induction of a deterrent compound restricted to the polar fraction of Galaxaura secondary metabolites, which would not have been extracted with dichloromethane during the preparation of artificial food, or to a morphological defensive trait. The deterrent polar fraction is commonly represented by polyphenols; however, this fraction in G. diessingiana was low, and was similar to that for the undefended kelp Ecklonia radiata, which has been described as a low polyphenol concentration alga (Steinberg and Van Altena 1992). Moreover, we observed no increase in the polyphenol levels in $G$. diessingiana when it was consumed. Recently it has been discovered that polyphenols are not the only deterrent compounds in the polar fraction. In Fucus vesiculosus, defence has been attributed to the polar galactolipids rather than polyphenols 
(Deal et al. 2003). As we did not measure these, it cannot be determined if such compounds could explain the lack of induction in our artificial assays. Induction of morphological anti-herbivore defence, such as changes in growth form (Lewis et al. 1987) or growth of adventitious branches (Van Alstyne 1989), has been documented for some brown algae. However, we did not observe any alteration to the growth patterns in G. diessingiana algal pieces following exposure to P. rubra. Alternatively, G. diessingiana might increase calcification levels in response to grazers to further increase tissue toughness and reduce its nutritive value (Cronin 2001). Solandt and Campbell (2001) reported that Galaxaura sp. individuals exhibit $70 \%$ calcification on average, suggesting that induced morphological defence in $G$. diessingiana is possible; however, we did not measure tissue toughness. Our results from the feeding assays may corroborate those of Del Val et al. (2001), who found antimicrobial activity of G. rugosa methanol extracts, because bio-active substances were absent from the non-polar fractions of Galaxaura extracts in both studies. Irrespective of whether defences were morphological or chemical or a combination of both (Hay et al. 1994; Hay 1997), our findings along with those of Weidner et al. (2004) and Ceh et al. (2005) for Pterocladiella capillacea and Hypnea pannosa, respectively, are among the first reports of inducible defences in red algae. In all three cases, defence was detected in assays of living tissue, but not in pellets based on non-polar extracts.

Inducible stimulation in Gracilaria capensis and Hypnea spicifera

Grazing of both G. capensis and H. spicifera resulted in increased grazing rates, suggesting an induction of grazer stimulation. However, this occurred in different ways for the two species. (1) Grazers showed no preference for artificial food containing non-polar G. capensis extracts, but when offered intact pieces, they preferred grazed over control algae. After the treatment phase, no visible changes in algal morphology were observed (Lewis et al. 1987; Van Alstyne 1989). We did not assess tissue toughness and so cannot exclude morphological plasticity. Neither did we isolate the polar fraction of this alga, which could explain the difference between intact and artificial feeding assays. (2) The snail Tricolia capensis, assayed with $H$. spicifera, showed no increase in consumption on the intact algal pieces, but a significant increase in the consumption of pellets containing nonpolar compounds (Fig. 2b).

Sakata et al. (1986) found compounds called feeding stimulants in some algae that promote ingestion and the continuation of feeding, and these can be ecologically important (Stachowicz 2001a). Treatments used to investigate inducible (Pavia et al. 1997) and activated (Cetrulo and Hay 2000) defences have led to both defence responses and stimulated grazer feeding. Such stimulation is an ambiguous response, because the alga seems to stimulate a decrease in its own fitness, and there are alternative interpretations. (1) An increase in palatability may be explained by the variability in responses of herbivores to different compounds (Hay and Fenical 1988). For example, Steinberg and Van Altena (1992) reported that secondary non-polar compounds can either attract the urchin Tripneustes grutilla at high concentrations or repel it at low concentrations. In addition, more than 400 different compounds have been reported in the genus Laurencia. Most repel fish, but others have no effect on them, and may repel other grazers (Hay et al. 1988). (2) Complex ecological interactions could ultimately increase the fitness of the alga and the grazer, for example by attracting grazers that clean the alga of epiphytes or possible competitors (Stachowicz 2001b). Such interactions have been described for aquatic plants (Underwood et al. 1992; Kerffoot et al. 1998; Jones et al. 1999) and terrestrial plants (Williams and Myers 1984).

We suggest that stimulation by an alga of its own consumption could reflect the results of complex mutualistic interactions that have not been extensively explored. There are no reported interactions between P. rubra and Tricolia capensis and we suggest that grazing induces defences against other grazers while simultaneously promoting grazing by $P$. rubra. Complex ecological interactions seem to explain the $T$. capensis$H$. spicifera effect. Since T. capensis is frequently found on the stipes of $H$. spicifera, an association between them could benefit both. The snail could remove competitors and epiphytes from $H$. spicifera, while receiving shelter and food from the alga. A similar pattern has been observed by Hay et al. 1990, in which the chemically defended alga Avrainvillea longicaulis provided shelter to the ascoglossan gastropod Costasiella ocellifera and the crab Thersandrus compressus. These grazers feed on the alga and receive chemical protection against fishes; however, the benefits to the alga are not mentioned. A similar example given by Stachowicz (2001b) for the decorator crab Libinia dubia and the alga Dictyiota menstrualis suggests that the alga can obtain nutrients from the crab excretions and at the same time the crab can remove herbivorous amphipods.

\section{Absence of induced defences in Codium extricatum}

For C. extricatum, no significant differences were detected between the treated algal pieces and the controls, in either intact or artificial feeding assays. This could be due to the presence of activated defences, or could simply mean that there are no chemical defences within these algae. We cannot discard the first possibility at least in regard to this particular grazer, as our experimental design was not sensitive enough to detect activated defences. Activated defences are a short-term mechanism, occurring in seconds. If the two algal pieces were damaged by Tricolia capensis, induction could have been shown by a significant reduction in the 
consumption of the alga either in the intact feeding assays or in the pellets. We observed considerable damage to the algae, presumably sufficient to induce chemical defences (Karban et al. 1997). It has been reported that C. extricatum has a high nutritive value (Foster and Hodgson 1998), which may override the effects of defences by secondary metabolites (Hay 1996). This result agrees with the lack of defence induction for other species of Codium spp. tested with mesograzers: $C$. decorticatum in Brazil (Weidner et al. 2004), C. tomentosum in Portugal and $C$. fragile in Sweden (M. Molis et al., unpublished data).

\section{Rudimentary alert system in Codium platylobium}

During this experiment a decrease in palatability relative to direct grazing was observed in two of the treatments (indirect grazing and presence of grazers) involving waterborne cues. Due to the lack of significant differences between controls and indirect treatments (presence of grazers and indirect grazing), we can only report a weak trend of reduction in palatability (Fig. 3). Indirect alert signals that can induce chemical defences have only been reported for the brown algae Aschophylum nodosum (Toth and Pavia 2000), Fucus serratus (Rohde et al. 2004) and Glossophora kunthii (Macaya et al. 2005).

Indirect grazing and presence of grazer treatments resulted in negative consumption rates, indicating that the grazers ate less than the alga grew during the experiment. Even though the growth rates of C. platylobium did not differ among treatments, there was negative consumption in the indirect grazing treatment (Fig. 3a), confirming that Turbo sarmaticus ate fewer pieces that had been indirectly grazed than directly grazed treatment pieces. Only indirect grazing (in intact assays) and the presence of the grazer (in artificial food assays) induced a decrease in palatability, suggesting the presence of a waterborne cue that may stimulate the production of secondary compounds originating from the grazer rather than the alga. The present results indicate that the presence of a predator in the vicinity of C. platylobium may alert neighbouring algae, stimulating the production of non-polar defensive chemicals and so reduce their palatability. We cannot report defence induction as neither indirect grazing nor the presence of grazer was significantly different from the control. Although, these results show that direct grazing is not the only mechanism that can induce responses, the discussion about whether direct damage plays the most important role in defence induction continues (Toth and Pavia 2000; Rhode et al. 2004; Macaya et al. 2005).

It is almost inevitable that algal-herbivore interactions will be complex and "non-linear" as they will be shaped by the effects of natural selection operating on shifting balances between costs and benefits for both the consumer and the prey (Stachowicz 2001a, b). There are both costs and benefits to an alga in the production of induced chemical defences and there are costs and benefits to a grazer in tolerating such defences. For example, geographic variability within a species may be a phenotypic response to the variable grazing intensity or may be explained by the concept of an evolutionary moving target (Adler and Karban 1994). This model assumes a population of plants, each of which responds to attack by altering its phenotype, but does not revert to the original phenotype in the absence of further attack. These phenotypic changes occur on ecological time scales, but are non-directional, as the plant can become either more or less vulnerable, making it difficult for the grazer to evolve the effectiveness of its attack on these plants. The present study reports plasticity in the response of green and red algae to grazers. We found preliminary evidence of an induced reduction of palatability in one red alga (Galaxaura diessingiana) and grazing stimulation in two. Neither of the green algae in the genus Codium showed induced defences, although $C$. platylobium tended to decrease its palatability when exposed to waterborne cues from the macrograzer T. sarmaticus. This variability could represent a strategy for avoiding some grazers while at the same time attracting others that may eliminate parasites or competitors. Such variability in the algal responses mediated by grazers has been shown in many studies in marine (Hay 1992, 1997; Steinberg and Van Altena 1992; Cetrulo and Hay 2000; Van Alstyne et al. 2001; Weidner et al. 2004) and terrestrial plants (see review by Nykänen and Joricheva 2004).

Acknowledgements Thanks are due to the Stiftung Mercator for provided funding for the project, to John Higgs for the loan of a sand filter during the experiment and to all correctors for suggestions on this manuscript. All the animals and algae used in this study were collected with the permission of the environmental affairs office of South Africa.

\section{References}

Adler FR, Karban R (1994) Defended fortresses or moving targets? Another model of inducible defenses inspired by military metaphors. Am Nat 144:813-832

Baldwin IT, Schultz JC (1983) Rapid changes in tree leaf chemistry induced by damage: evidence for communication between plants. Science 221:277-279

Bruin J, Sabelis MW, Dicke M (1995) Do plants tap SOS signals from their infested neighbours? Tree 4:167-170

Carpenter RC (1986) Partitioning herbivory and its effects on coral reef algal communities. Ecol Monogr 56:345-363

Ceh J, Molis M, Dzeha TM, Wahl M (2005) Induction and reduction of antihervibore defenses in brown and red macroalgae off the Kenyan Coast. J Phycol 41:726-731

Cetrulo G, Hay ME (2000) Activated chemical defenses in tropical versus temperate seaweeds. Mar Ecol Prog Ser 207:243-253

Cronin G (2001) Resource allocation in seaweeds and marine invertebrates: chemical defense patterns in relation to defense theories. In: McClintock JB, Baker BJ (eds) Marine chemical ecology. CRC Press, Boca Raton, pp 325-353

Cronin G, Hay ME (1996) Induction of seaweed chemical defenses by amphipod grazing. Ecology 77:2287-2301

Deal MS, Hay ME, Wilson D, Fenical W (2003) Galactolipids rather than phlorotannins as herbivore deterrents in the brown seaweed Fucus vesiculosus. Oecologia 136:107-114 
Del Val A, Platas G, Basilio A, Cabello A, Gorrochategui J, Suay I, Vicente F, Portillo E, Jiménez del Río M, García Reina G, Peláez F (2001) Screening of antimicrobial activities in red, green and brown macroalgae from Gran Canaria (Canaria Isalnd, Spain). Int Microbiol 4:35-40

Duffy JE, Hay ME (1991) Food and shelter as determinants of food choice by an herbivorous marine amphipod. Ecology 72:1286-1298

Duffy JE, Hay ME (1994) Herbivore resistance to seaweed chemical defense: the roles of mobility and predation risk. Ecology 75:1304-1319

Foster G, Hodgson AN (1998) Consumption and apparent dry matter digestibility of six intertidal macroalgae by Turbo sarmaticus (Mollusca: Vetigastropoda: Turbinidae). Aquacul 167:211-227

Hammerstrom K, Dethier MN, Duggins DO (1998) Rapid phlorotannin induction and relaxation in five Washington kelps. Mar Ecol Prog Ser 165:293-305

Hay ME (1992) The role of seaweed chemical defenses in the evolution of feeding specialization and in the mediation of complex interactions. In: Paul VJ (ed) Ecological roles of marine natural products. Comstock Publishing Associates, Ithaca, pp 93-118

Hay ME (1996) Marine chemical ecology: what's known and what's next? J Exp Mar Biol Ecol 200:103-134

Hay ME (1997) The ecology and evolution of seaweed-herbivore interactions on coral reefs. Coral Reefs 16:S67-S76

Hay ME, Fenical W (1988) Marine plants-herbivore interactions: the ecology of chemical defences. Annu Rev Ecol Syst 19:111145

Hay ME, Renaud PE, Fenical W (1988) Large mobile versus small sedentary herbivores and their resistance to seaweed chemical defenses. Oecologia 75:246-252

Hay ME, Duffy JE, Paul VJ, Renaud PE, Fenical W (1990) Specialist herbivores reduce their susceptibility to predation by feeding on the chemically defended seaweed Avrainvillea longicaulis. Limnol Oceanogr 35:1734-1743

Hay ME, Kappel QE, Fenical W (1994) Synergism in plant defenses against herbivores: interactions of chemistry, calcification, and plant quality. Ecology 75:1714-1726

Jones JI, Young JO, Haynes GM, Moss B, Eaton JW, Hardwick KJ (1999) Do submerged aquatic plants influence their periphyton to enhance the growth and reproduction of invertebrate mutualist? Oecologia 120:463-474

Karban R, Agrawal AA, Mangel M (1997) The benefits of induced defenses against herbivores. Ecology 78:1351-1355

Kazlauskas R, Mulder J, Murphy PT, Wells RJ (1980) New metabolites from brown alga Caulocystis cephalornithos. Aust $\mathbf{J}$ Chem 33:2097-2101

Kazlauskas R, King L, Murphy PT, Warren RG, Wells RJ (1981) Metabolites from brown algal genus Cystophora. Aust J Chem 34:439-447

Kerffoot WC, Newman RM, Hanscom Z (1998) Snail reaction to watercress leaf tissues: reinterpretation of a mutualistic 'alarm' hypothesis. Freshwater Biol 40:201-213

Lewis SM, Norris JN, Searles RB (1987) The regulation of morphological plasticity in tropical reef algae by herbivory. Ecology 68:636-641

Lindsay JR (1998) Effects of zone and wave exposure on population structure and recruitment of the mussel (Perna perna) in South Africa. Master of Science thesis, Rhodes University

Littler MM, Littler DS (1980) The evolution of thallus form and survival strategies in benthic marine macroalgae: field and laboratory tests of a functional form model. Am Nat 116:25-44

Lubchenco J, Gaines SD (1981) A unified approach to marine plant-herbivore interactions. I. Populations and communities. Ann Rev Ecol Syst 12:405-437

Macaya EC, Rothäusler E, Thiel M, Molis M, Wahl M (2005) Induction of defenses and within-alga variation of palatability in two brown algae from northern-central coast of Chile: effects of mesograzers and UV radiation. J Exp Mar Biol Ecol $325: 214-227$
McQuaid CD, Froneman PW (1993) Mutualism between the territorial intertidal limpet Patella longicosta and the crustose alga Ralfsia verrucosa. Oecologia 96:128-133

Nykänen H, Koricheva J (2004) Damage-induced changes in woody plants and their effects on herbivore performance: a meta-analysis. Oikos 104:247-268

Paul VJ, Van Alstyne KL (1992) Activation of chemical defenses in the tropical green algae Halimeda spp. J Exp Mar Biol Ecol 160:191-203

Paul VJ, Cruz-Rivera E, Thacker RW (2001) Chemical mediation of macroalgal-herbivore interactions: ecological and evolutionary perspectives. In: McClintock JB, Baker BJ (eds) Marine chemical ecology. CRC Press, Boca Raton, pp 227-265

Pavia H, Toth GB (2000) Inducible chemical resistance to herbivory in the brown seaweed Ascophyllum nodosum. Ecology 81:3212-3225

Pavia H, Cervin G, Lindgren A, Aberg P (1997) Effect of UV-B radiation and simulated herbivory on phlorotannins in the brown alga Ascophyllum nodosum. Mar Ecol Prog Ser 157:139146

Peckol P, Krane JM, Yates JL (1996) Interactive effects of inducible defense and resource availability on phlorotannins in the North Atlantic alga Fucus vesiculosus. Mar Ecol Prog Ser 138:209-217

Rohde S, Molis M, Wahl M (2004) Regulation of anti-herbivore defence by Fucus vesiculosus in response to various cues. J Ecol 92:1011-1018

Sakata K, Tsuge M, Ina K (1986) A simple bioassay for feeding stimulants for the young sea hare Aplysia juliana. Mar Biol 91:509-511

Solandt JL, Campbell AC (2001) Macroalgal feeding characteristics of the sea urchin Diadema antillarum Philippi at Discovery Bay, Jamaica. Caribb J Sci 37:227-238

Sotka E, Taylor RB, Hay ME (2002) Tissue-specific induction of resistance to herbivores in a brown seaweed: the importance of direct grazing versus waterborne signals from grazed neighbours. J Exp Mar Biol Ecol 277:1-12

Stachowicz J (2001a) Chemical of mobile benthic invertebrates: predators and prey, allies and competitors. In: McClintock JB, Baker BJ (eds) Marine chemical ecology. CRC Press, Boca Raton, pp 157-194

Stachowicz J (2001b) Mutualism, facilitation, and the structure of ecological communities. BioScience 51:235-246

Steinberg PD (1994) Lack of short-term induction of phlorotannins in the Australasian brown algae Ecklonia radiata and Sargassum vetitum. Mar Ecol Prog Ser 112:129-133

Steinberg PD, Van Altena I (1992) Tolerance of marine invertebrate herbivores to brown algal phlorotannins in temperate Australasia. Ecol Monogr 62:189-222

Steinberg PD, De Nys R, Kjelleberg S (2001) Chemical mediation of macroalgal-herbivore interactions: ecological and evolutionary perspectives. In: McClintock JB, Baker BJ (eds) Marine chemical ecology. CRC Press, Boca Raton, pp 355-387

Steneck RS, Watling L (1982) Feeding capabilities and limitations of herbivorous molluscs: a functional group approach. Mar Biol 68:299-319

Taylor RB, Sotka E, Hay ME (2002) Tissue-specific induction of herbivores resistance: seaweed response to amphipod grazing. Oecologia 132:68-76

Toth GB, Pavia H (2000) Water-borne cues induce chemical defense in a marine alga (Ascophyllum nodosum). Proc Natl Acad Sci USA 97:14418-14420

Underwood AJ (1997) Experiments in ecology: the logical design and interpretation using analysis of variance. University Press, Cambridge

Underwood AJ, Jernakoff P (1984) The effects of tidal height, wave-exposure, seasonality and rock-pools on grazing and the distribution of intertidal macroalgae in New Wales. J Exp Mar Biol Ecol 75:71-96

Underwood GJC, Thomas JD, Baker JH (1992) An experimental investigation in snail-macrophyte-epiphyte systems. Oecologia 91:587-594 
Van Alstyne KL (1988) Herbivore grazing increases polyphenolic defenses in the intertidal brown alga Fucus distichus. Ecology 69:655-663

Van Alstyne KL (1989) Adventitius branching as an herbivoreinduced defense in the brown alga Fucus distichus. Mar Ecol Prog Ser 56:169-176

Van Alstyne KL (1995) Comparison of three methods for quantifying brown algal polyphenolic compounds. J Chem Ecol 21:45-58

Van Alstyne KL, Wolfe GV, Freidenburg TL, Neil A, Hicken C (2001) Activated defense system in marine macroalgae: evidence for an ecological role for DMSP cleavage. Mar Ecol Prog Ser 213:53-65
Waterman PG, Mole S (1994) Analysis of phenolic plant metabolites. Blackwell Scientific Publications, Oxford

Weidner K, Lages BG, da Gama BAP, Molis M, Wahl M, Pereira RC (2004) Effect of mesograzers and nutrient levels on induction of defenses in several Brazilian macroalgae. Mar Ecol Prog Ser 283:113-125

Williams KS, Myers JH (1984) Previous herbivore attack of red alder may improve food quality for fall webworm larvae. Oecologia 63:166-170

Yates JL, Peckol P (1993) Effects of nutrient availability and herbivory on polyphenolics in the seaweed Fucus vesiculosus. Ecology 74:1757-1766 